\title{
Cardinal Pietro Boetto: A Life of Service to the Society of Jesus, the Catholic Church, and the People of Genoa
}

\author{
Susan Zuccotti \\ Independent Scholar, New York, NY, UsA \\ sszuccotti@gmail.com
}

\begin{abstract}
Cardinal Pietro Boetto, archbishop of Genoa from 1938 until his death in 1946, was an unusual Jesuit priest in several respects. First, although from humble origins, trained in seminaries other than the most prestigious Jesuit institutions, and not given to complex theological writings, he rose through the ranks of the Society's administration to attract the notice of Pope Pius XI and be elevated to the cardinalate in 1935. The elevation was in itself highly unusual, given standard Jesuit policy and the expressed reluctance of the order's Superior General Włodzimierz Ledóchowski at the time. Equally unexpected is the fact that the Jesuit Father Pietro Tacchi Venturi, the pope's liaison with Mussolini, furnished intriguing background testimony about the elevation itself, which provides new insight into the pope's policies and modes of operation. Finally, Cardinal Boetto was unusual for the clandestine assistance to Jews and anti-Fascists he provided as archbishop during the German occupation, for the broad range of rescue activities he allowed to his heroic secretary don Francesco Repetto and other priests, and for the wide-spread support networks that resulted throughout Northern and Central Italy. This article tells the story of a competent administrator with immense hidden skills and profound humanity. Sources include the memoirs of Boetto's aide, Brother Giovanni Battista Weidinger; a biography by his associate Father Arnaldo Lanz; testimony by don Francesco Repetto; documents in the Archivum Romanum Societatis Iesu in Rome and the Archivio Diocesano di Genoa; and secondary studies by historians interested in the Second World War and the rescue of Jews in Genoa.
\end{abstract}




\section{Keywords}

Pietro Boetto - Jesuit cardinal - archbishop of Genoa - rescue of Jews - Pius XI - Pius XII - Włodzimierz Ledóchowski - Pietro Tacchi Venturi - Delasem - Lelio Vittorio Valobra - Francesco Repetto

\section{Introduction}

The nation where Pietro Boetto was born on May 20, 1871, and the church into which he was christened a few days later, were vastly different institutions from those he left behind when he died seventy-four years later. Italy as we know it, though still without Trent and Trieste, was only eight months old at the time of his birth. The army of King Victor Emanuel II (r.1861-78) had breached the Porta Pia Gate, entered Rome, and forcibly seized the Papal States from Pope Pius IX (r.1846-78) on September 20, 1870. The enraged pope had declared himself a "prisoner in the Vatican," refused to recognize the Kingdom of Italy, ordered the faithful to withhold support from the new nation, and excommunicated the king and other prominent Italian leaders. Pius Ix had already, in 1864, issued a syllabus condemning political liberalism, socialism, and communism; freedom of religion, separation of church and state, and modern civilization in general. And because Jews seemed to be the beneficiaries of liberalism and modernism, the condemnation came to have a broad anti-Semitic dimension also. Boetto would be raised and formed as a Jesuit priest in this context.

As will be seen, Boetto was serving as a Jesuit visitor in Spain during much of the immediate post-World War One ferment that preceded Benito Mussolini's (1883-1945) rise to power. But he would have been aware of the brutality and violence of the battles between trade unionists, agricultural workers, Socialists, and Communists on the one hand and Fascist squadristi on the other, and he may have agreed with many middle-of-the-road Italians who hoped that a government headed by Mussolini would restore order and put an end to the bloodshed. By October 1921, however, Boetto was back in Rome and able to witness the struggle personally. He was also there one year later, at the time of the March on Rome in late October 1922, when some thirty thousand Fascist militants gathered outside the city and threatened to invade. King Victor Emanuele III (r.19oo-46) caved under the pressure and called upon Mussolini to form a government. The Fascist regime that would destroy democracy and 
human rights in Italy and take the country into the Second World War on the side of the Third Reich in June 1940 was on its way.

Pius XI (r.1922-39), who became pope in the same year that Mussolini became head of government, was not entirely displeased with these political developments. Anxious to end the conflict between church and state, obtain a legal definition of the status of the Vatican, and insert his own preferences and priorities into government programs, the pope thought he saw someone with whom he could work. Mussolini in turn welcomed the seal of legitimacy and approval that the pope could provide. Pius XI's first objectives were secured with the signing of the Lateran Accords in 1929, by which Italy recognized, among other things, the inviolability of the 108.7 acres of the Vatican City State and the special status of many additional properties outside the walls. The Holy See in turn recognized the Italian state, with Rome as its capital. Roman Catholicism became the official religion of the nation.

The Lateran Accords eased the way toward reconciliation, but old wounds took a long time to heal. Radical Fascists remained as hostile to the church as the extreme leftists were, and many Catholics continued to feel under siege. Vatican spokesmen and Italian Catholic priests and prelates, including Jesuits, still needed to defend themselves against liberalism, modernism, socialismin short, against the entire outside secular world—or so many of them believed. The complex process by which these leaders of the church came to broaden the scope of their social commitment and concern-a process also greatly facilitated by threats to the Italian nation during both the First and the Second World Wars - continued well into the second half of the twentieth century. Pietro Boetto was in the forefront of this process. His life would be one of great intellectual and spiritual growth; a symbol of significant change. It is a story that deserves to be told.

Pietro Boetto was born in Vigone di Torino, in the region of Piedmont, Italy. Just thirty kilometers southwest of the regional capital of Turin, Vigone was situated on a rich agricultural plain within sight of the Italian Alps. The town contained seven churches and several attractive public buildings and squares, but many of its 6,689 inhabitants in 1871 worked in the surrounding fields and meadows. Boetto's father Antonio, a small landholder and farmer, was one of them. Antonio and his wife Caterina Anghilano would eventually have six children, three boys and three girls. ${ }^{1}$

1 Arnaldo M. Lanz, S.J., Il Cardinale Pietro Boetto S.I., arcivescovo di Genova (1871-1946) (Isola Del Liri: Casa Editrice Pisani, 1949), 41. Father Lanz knew and worked with Cardinal Boetto 
With their deep respect for education and the Catholic Church, the Boettos were representative of many Piedmontese farm folk at the time. Church schools, rather than secular and often anti-clerical government institutions, offered reassuring and affordable opportunities to boys from families like theirs. At the age of twelve, therefore, Pietro entered the diocesan Seminario San Lorenzo Martire, in the nearby town of Giaveno, about thirty kilometers west of Turin. After about four years there, he proceeded to the Jesuit novitiate in Chieri, a larger town about eleven kilometers southeast of Turin. He later liked to recall that on January 31,1888 , en route to Chieri, he passed through Turin on the day of the death in that city of don Giovanni Bosco (1815-88). ${ }^{2}$ Like Boetto but probably in more impoverished circumstances, don Bosco was born in a small Piedmontese town near Turin. After entering the Oratorian seminary adjacent to the Church of the Immacolata Concezione in Chieri in 1835, in the same town where Boetto would enter the novitiate some fifty years later, he went on to become a revered priest, educator, and founder of the Salesian Order, and was canonized in 1934. To the young Boetto, the coincidence of being in Turin on the day of don Bosco's death was an honor, an inspiration, and a favorable omen.

Boetto would spend at least six years in Chieri. He later spoke of that time as an especially happy and peaceful period in a beautiful location. His two years as a Jesuit novice lasted from 1888 to 1890 . He then took his initial vows of poverty, chastity, and obedience on September 8, 1890, and embarked on what the Jesuits called "first studies." These consisted of, first, an intense focus on the humanities, such as Greek and Latin classics; Italian and other literature, including, according to one man who knew him, even the poetry of John Keats (1795-1821); philosophy, physics, and other sciences. ${ }^{3}$ The years 1894 to 1898 involved an interval at the College of the Visitation in Monaco, where he taught in a secondary school. Known as the magistero (regency), that interval between the study of philosophy and a concentration on theology was a requirement of Jesuit formation. After Monaco came four more years of rigorous theological studies.

for many years and conducted extensive archival research for his biography. He quotes a document in which Boetto wrote that he was born on May 20 and had two brothers and three sisters. This seems conclusive, although accounts by others sometimes claim May 19 as his date of birth and state that he had just one brother in addition to sisters.

2 Lanz, Cardinale Pietro Boetto, 29.

3 Lanz, Cardinale Pietro Boetto, 53. Information regarding Cardinal Boetto's early years and Jesuit formation is from Lanz, updated by, among others, Giovanni Battista Varnier, "Boetto, Pietro," in Dizionario storico del movimento cattolico in Italia, III/1 (Casale Monferrato: Marietti, 1984), 99-100; and Danilo Veneruso, "Boetto, Pietro," in Dizionario Biografico degli Italiani, http://www.treccani.it/enciclopedia/pietro-boetto_(Dizionario-Biografico)/. 
Boetto's ordination occurred on July $28-30,1901$. The young priest was then required to undergo one additional year of theological studies and another of probation before he could enter into a direct apostolate. During this period, he was sent to Genoa in 1902 to serve at the Istituto Arecco, a prestigious Jesuit secondary school. An important seaport and the bustling capital of the region of Liguria, just south of Piedmont, Genoa had long attracted young Piedmontese men seeking employment in a major city. Boetto would have felt comfortable and pleased to be there. His assignment was of a teaching, administrative and organizational nature, similar to others of ever-increasing importance that he would receive in the future.

In 1904 and 1905, after Genoa, Father Boetto underwent what was called a third probation or tertianship, serving in the small Piedmontese town of Avigliana as an assistant teacher of Jesuit novices. He was then sent to the Collegio San Tomaso d'Aquino, an elementary and secondary school in Cuneo. Again, his assignment involved administration and teaching. Cuneo, also in Piedmont, was an attractive city in the foothills of the Italian Alps, and the young man would have felt quite at home.

On February 2, 1906, in Cuneo, Father Boetto underwent the final step in his formation as a Jesuit priest by making his solemn profession of final vows. These vows consisted again of poverty, chastity, and obedience, but they now included the "fourth vow," unique to Jesuits, by which the professed priest promised special obedience to the pope with regard to any missions the holy father might designate. In addition, in a step that would become intensely relevant in the future, Boetto, like all Jesuit professed of the four vows, promised not to seek any offices outside or within the order. If, despite not seeking advancement or promotion, he was chosen for an ecclesiastical office outside the Jesuit order including that of bishop, he promised to remind the appointing authority, including the pope, of his vows as a Jesuit and of the fact that he would always be obligated to remain in contact with and receive advice from the Jesuit superior general.

Presumably some members of Boetto's family were present on important occasions such as his ordination or his profession of final vows. Unfortunately, surviving documents record little about his personal life, particularly at this early stage. One wonders, for example, whether he enjoyed the countryside and the mountains near where he studied. Did he go for walks, hikes, or ski trips? Did he ever travel or take a vacation? In any case, he was not long in Cuneo after his profession of final vows, for in 1907 he was called to serve in Turin, the center of the Jesuit province of the same name. A province in this sense was one of the territorial units around which the Society of Jesus was organized. The Province of Turin, one of five in Italy at the time, included 
Liguria, Corsica, and Sardinia as well as Piedmont. Boetto would remain there for twelve years.

Boetto's first position in Turin was that of assistant to the procurator. A procurator, in this case, may be understood as a kind of treasurer or bursar, with administrative and financial responsibilities for particular properties or schools. With time, Boetto's responsibilities increased and his changing positions, some times difficult to decipher, were called coadiutore, consultore, and ammonitore. Eventually he became the procurator of the Jesuit residence in Turin and then, in November 1916, the provincial. In the last role, he had full oversight over the entire province. He would remain in that position throughout the final years of the First World War (1914-18) and until 1919.

The war years were difficult for all Italians, and the Jesuits were not excepted. Of 275 Jesuits under Boetto's jurisdiction in 1916, thirty-eight had been drafted, three as military chaplains and others as medics or common soldiers. The total number called up reached fifty-five in 1917 and 106 in 1918, well over a third of the Jesuit priests and brothers in the province. ${ }^{4}$ Men qualified to staff local Jesuit institutions became scarce and supplies were hard to find. Boetto's biographer later wrote of civilian hostility to the Society after the Italian defeat at Caporetto in October 1917, an attitude that included blaming the order for the war itself. ${ }^{5}$ The author may have been exceptionally sensitive to public criticism, but there is no doubt that the Jesuits were unpopular among increasingly radical anti-clerical and anti-war elements of the population. At the same time, toward the end of the war came the influenza pandemic. Schools closed and Jesuits helped tend the sick. Hundreds of thousands died throughout the country.

In 1919, Boetto was sent to Spain to serve as visitor in the Jesuit Province of Aragon, which included Catalonia at that time. A Jesuit visitor was appointed by the order's superior general to deal with particularly difficult local circumstances and problems. Boetto travelled to many cities, including Barcelona, Valencia, Alicante, Zaragoza, and others. After about a year, he was transferred to the Jesuit Province of Castile, where he visited Madrid, Burgos, Valladolid, Salamanca, Santander, and others. He encountered numerous difficulties in both provinces, for Spain was experiencing the effects of the 1918 influenza pandemic, a general post-war economic slowdown, labor unrest and strikes, a colonial war in Morocco, Catalonian separatism, and the growing political dissent that would lead, in 1931, to the deposition of King Alfonso XIII (r.18861931) and the establishment of the Second Spanish Republic (1931-39).

4 Lanz, Cardinale Pietro Boetto, 141-42.

5 Lanz, Cardinale Pietro Boetto, 149. 
In the Province of Aragon, one of Boetto's problems involved the status of the Catalan language. Most Jesuits in Catalonia favored official tolerance of the local language as a way to reach the faithful. The Spanish central government opposed it until the onset of the republic, when most restrictions were lifted until the installation of the Francisco Franco (1892-1975) regime after the Spanish Civil War (1936-39). Another problem, this time in both provinces, involved the bitter conflicts between secular and often anti-clerical liberals and the church. During the first decades of the twentieth century, many Spanish Jesuits were closely allied with the Integrists, Carlists, and other conservative, monarchist, and nationalist factions regarding issues such as the church's role in education, marriage, and divorce. Spanish Jesuits during these years led a movement to spread the cult of the Sacred Heart and install symbols of observance in public and private offices, schools, banks, and other institutions, arousing the ire and opposition of secularists. With both of these issues, Boetto displayed exceptional diplomatic skill, sensitivity, and tact. He supported the use of Catalan in the first case, angering some Spanish politicians and bureaucrats but gratifying local Jesuits. In the second case, he advised Jesuits to steer clear of inflammatory conservative positions and endorse moderation. ${ }^{6}$

In 1921, Boetto was called from Spain to Rome to serve as procurator general of the entire Jesuit order. He was clearly recognized for his abilities and judgment, for in 1928 he was named provincial of the Jesuit Province of Rome, despite the fact that it was unusual for such an appointment to go to a Jesuit not linked by birth and experience to the province concerned. ${ }^{7}$ In 1930, he received the title of assistant to the superior general for Italy, with oversight over all Jesuit provinces in the country. He remained in that position until he was made a cardinal in 1935. As the years passed, he had almost daily contact with Vatican officials and came to know many of the most important cardinals in the Roman Curia. He was also part of the highest levels of governance of the Jesuit order. Especially between 1930 and 1935, he was, according to his biographer, an "intimate advisor" to the Curia Generalizia and to the Jesuit Superior General Włodzimierz Ledóchowski (in office 1915-42). ${ }^{8}$

Despite their similarities in age, few Jesuits could have been more different in background than Ledóchowski and the priest from a small town in Piedmont. The former, born in 1866, was a Polish nobleman who had served as a page at the Hapsburg court. His uncle, moreover, had been the cardinal primate of Poland and a member of the Roman Curia. Educated at the

6 Giacomo Martina, S.J., "La mancata nomina cardinalizia del P. Tacchi Venturi: Relazione dell'interessato," in Archivum historicum Societatis Iesu 65 (1996): 101-9, at 105.

7 Martina, "La mancata nomina," 105.

8 Lanz, Cardinale Pietro Boetto, 210. 
prestigious Jagellonian University in Cracow and the Gregorian University in Rome, Ledóchowski's academic credentials matched his lineage. On the other hand, the career paths of the two men were remarkably similar. In positions resembling Boetto's, Ledóchowski had served as a Polish Jesuit vice-provincial in 1901, the provincial of Southern Poland in 1902, and an assistant in the German province from 1906 to 1915 . He was elected superior general of the Society of Jesus in 1915, at the age of forty-nine. Similar in career, then, but it is not certain to what extent Boetto shared Ledóchowski's political ideas. The latter often expressed sympathy for Mussolini's Fascist regime and occasionally revealed anti-Semitic sentiments, most notably when he apparently stalled Pope Pius XI's now well-known "hidden encyclical" attacking racism in $1939 .{ }^{9}$ Boetto was no longer a close advisor to Ledóchowski at that time, and his own views on the burning issues of Fascism and anti-Semitism before the Second World War (1939-45) are not clear.

More difficult than tracing Father Boetto's advancement within the Society of Jesus is the effort to describe his personality and the special qualities that made him so successful. He seems to have been an intensely private person. Fortunately, however, a few of the many associates who admired him have left written records. One Jesuit based in India wrote that several priests working with him there in the 1960s remembered how kind Boetto had been to them years before, when he, Boetto, as official visitor, met them at their novitiate in Spain in 1920. Boetto had discovered at that time that several of the novices suffered from headaches and arranged that they should have a walk or games every afternoon..$^{10}$ A seemingly simple and obvious thing, but they appreciated and never forgot it. Other colleagues who knew Boetto well wrote to his biographer after his death in 1946. Cardinal Francesco Marchetti-Selvaggiani (1871-1951), for example, vicar of Rome during the German occupation and dean of the College of Cardinals from 1948 until his death in 1951, recalled, from their many years of working together, Boetto's "good sense" and his "imperturbable serenity founded on the most solid and continually envisioned Jesuit spirituality."11

Another who remembered Boetto was Cardinal Gennaro Granito Pignatelli di Belmonte (1851-1948), Cardinal Marchetti-Selvaggiani's predecessor as dean

\footnotetext{
9 David I. Kertzer, The Pope and Mussolini: The Secret History of Pius XI and the Rise of Fascism in Europe (New York: Random House, 2014), 233-35, 287-91, and 363-64; and Georges Passelecq and Bernard Suchecky, The Hidden Encyclical of Pius XI, trans. Steven Rendall (New York: Harcourt Brace, 1997).

10 Jerome Aixala, S.J., Black and Red S.J.: A Study in Ecclesial Service from Trent to Vatican II (Bombay: St. Xavier's High School, 1968), 291-92.

11 Lanz, Cardinale Pietro Boetto, vii-viii.
} 
of the College of Cardinals, who died in 1948. This older cardinal, who had presided over Boetto's episcopal consecration as archbishop of Genoa on April 24, 1938, wrote of the younger man's "humility and goodness."12 Also, but in more detail, Archbishop Giuseppe Siri (1906-89), who had served as Cardinal Boetto's auxiliary bishop during the war and succeeded him when he died, wrote of his sensitivity and friendly smile but also stressed his immense courage in dealing with the German occupiers of Genoa during the war. Siri testified that Boetto was "always in control of himself, self-contained and measured, prudent, and cautious in judging others," but "once he was convinced of the will of God, he had the decisiveness of a lion." Once he made a decision, Siri continued, he had "great calm and extraordinary foresight. He was then, in an exceptional manner, a man who could govern."13

Perhaps the person who worked the longest and most consistently with Boetto was the Jesuit Brother Giovanni Battista Weidinger (1890-1970), whose association with him began in 1921 and lasted until the cardinal's death. "He was tireless in his work and very efficient," Weidinger later wrote, "and he did not spare his assistants toward whom, however, he was always very grateful for whatever help they gave him." According to Weidinger, Boetto, as archbishop of Genoa after 1938, could be severe with priests and brothers under his supervision. He gave no quarter, for example, to any who chose to leave the order, except for two priests who left because they were ill, and he criticized those who were not acting as he felt they should. On the other hand, he was always available to advise religious who were wayward and in trouble, should they seek his help in good faith. ${ }^{14}$

On a more personal level, Weidinger also remembered Boetto's kindness and generosity to himself. The archbishop and his assistant often travelled together, usually to Rome or to more remote dioceses, and the trips were not always easy. Boetto was always concerned about Weidinger's comfort, sharing provisions, asking if he required a hot meal, giving him the best seat on the train, and offering him his own coat. And Boetto could be a lively and enjoyable companion. He was a fanatic about bocce and played it ferociously even after he became a cardinal. He enjoyed gardening, although Weidinger did not

12 Lanz, Cardinale Pietro Boetto, $\mathbf{x}$.

13 Lanz, Cardinale Pietro Boetto, xii.

14 Quotations and personal information in this and in the next two paragraphs are from Giovanni Battista Weidinger, "Memorie sulla vita del Card. Pietro Boetto, arcivescovo di Genova dalla sua creazione a cardinale (1935) sino alla sua santa morte," and "Memorie sul compianto Cardinale Pietro Boetto-Arcivescovo di Genova (1938)," at Archivum Romanum Societatis Iesu [hereafter ARSI], Vitae, 1055. 
describe how or where he was able to do that. He did not drink except on special occasions or formal visits, but when he did accept a glass of wine, he preferred Barolo, a premier product of Piedmont. He demonstrated affection for his region and town of birth in many other ways. After all the ceremonies involved in his consecration as the new archbishop of Genoa in late April 1938, he received a delegation of officials and friends from his hometown of Vigone and exchanged stories of his childhood and education at length, always speaking in the Piedmontese dialect. But his most memorable demonstration of local attachments had come a few days prior to that when, as newly appointed archbishop but still in Rome, he had a twenty-minute private audience at the Quirinale Palace with King Victor Emanuele on April 20, 1938. With both men speaking Piedmontese, Cardinal Boetto was delighted to learn that among the many titles of this king from House of Savoy was that of conte, or count, of Vigone.

Weidinger rarely mentioned visits by Boetto to his hometown. One visit, mentioned but not described in detail, occurred in 1936. Another, in early September 1938, took place after he had become archbishop. After all the church festivities at that time, Archbishop Boetto toured the town and passed in front of his old home, by then occupied by others. Little is known of Boetto's relationships with his family. Weidinger wrote that he revered his mother and also spoke occasionally of his father and of a sister who had died young. But he never mentioned his brother Nicola until he learned that he had died in Turin. At that point, he told Weidinger that Nicola had disgraced the family through drink and spent the entire family patrimony. Likely, Boetto's reluctance to drink alcohol was related to that tragedy.

The personal qualities that contributed to Cardinal Boetto's advancement and success are evident from the testimonies of those who knew him. Strong religious devotion, wisdom and good judgment, severity and compassion, seriousness and a sense of humor, an unrelenting capacity for hard work, all made him stand out as a candidate for promotion. But in addition to personal testimonies, his competence is evident from his written reports, often dating from an early period in his career. His responses were distinctly modern in nature. Typed rather than hand-written in the pinched, almost illegible script so often found in official bureaucratic reports from this period, his answers were succinct and straight to the point. There were none of the lengthy, timewasting, officious and obsequious introductions and conclusions that must have been so exasperating at the time. Instead, Boetto demonstrated an acute understanding of the complexities and subtleties of the problems and then offered clear suggestions about what should be done. And his responses were 
extraordinarily prompt, sometimes submitted just a day after receipt of the request. His superiors must have found him refreshing indeed. ${ }^{15}$

Father Boetto had been serving in Rome in some of the most important positions of the Society of Jesus for nearly fifteen years when Pope Pius XI, in anticipation of a consistory for the appointment of twenty new cardinals to be held in mid-December 1935, decided that he wanted to include a Jesuit. There was no Jesuit in the College of Cardinals at the time, and it is thought that the pope was anxious to express his gratitude for the many services he had received from Superior General Ledóchowski and members of the Society. ${ }^{16}$ The most obvious candidate for elevation was Father Pietro Tacchi Venturi (18611956). Born in San Severino Marche, in the province of Macerata, Tacchi Venturi had studied at the Gregorian University and the Sapienza in Rome, among other institutions, and was a noted historian, literary scholar, and author. In 1914, he was chosen by Ledóchowski's predecessor to be secretary general of the Jesuit order, a position he continued to hold under Ledóchowski himself until 1921. After Benito Mussolini became head of the Italian government in 1922, he emerged as the Duce's favorite priest and served as his personal confessor. With time he became an unofficial liaison between Mussolini and Popes Pius XI and Pius XII (r.1939-58). In that capacity in the late 1920 and early 1930s, he played a leading role most particularly in negotiations between Mussolini and Pius XI regarding Azione Cattolica.

Tacchi Venturi was not a perfect candidate for elevation. A favorite of Mussolini and others in the Fascist hierarchy, he was open to criticism for having a power base separate from both the Vatican and the Society of Jesus. He was also known to be anti-Semitic, although perhaps no more so than many other Catholic priests and prelates in Italy at the time. More serious were allegations of an apparent assassination attempt in 1928, believed by some to be linked to a homosexual affair. ${ }^{17}$ The latter accusation was never proven, but it can hardly have endeared him to his superiors in the Jesuit order.

15 For a representative sample of Boetto's reports while procurator and provincial in Turin in 1916 and 1917, see ARSI, 1015, Taurinensis 1911-20, Pars II Miscell., folder IX, docs. 22, 44, $47,50,51$, and 61 .

16 Martina, "La mancata nomina," 102-3.

17 On the assassination attempt, see Kertzer, Pope and Mussolini, 90-94. Kertzer, Pope and Mussolini, 88-9o, also provides evidence of Tacchi Venturi's anti-Semitism before 1935. He then points to Tacchi Venturi's lukewarm interventions with Mussolini at the time of the proclamation of the Italian racial laws in 1938 and 1939 on behalf only of Jews who had converted or were in mixed marriages. But the most convincing evidence of Tacchi 
Many Vatican and Italian government officials, including Tacchi Venturi himself, seemed to believe in 1935 that the priest who was Pope Pius XI's unofficial but effective liaison to Mussolini deserved to be elevated to the cardinalate in recognition of his services to the church. But to the general surprise, it was not to be. About a decade later, Tacchi Venturi wrote somewhat defensively that he had been the pope's strong first choice and offered his own explanation of why it did not happen. The precise date of the document is not certain, but it was probably written in $1945 .{ }^{18}$ Pius XI and Ledóchowski, who died in February 1939 and December 1942 respectively, would not have known of it. Boetto, who died on January 31, 1946, may have been informed.

In a rare glimpse into a private audience with the pope, Tacchi Venturi revealed that he had met with Pius XI and his secretary of state, Cardinal Eugenio Pacelli, on January 9, 1936, less than a month after the failed appointment. Before discussing the business at hand, the pope declared, "Poor Father, the cardinal's hat should have gone to you. But how could it have been? 1) It was not possible to name two Jesuits as cardinals at the same time; who knows how much gossip would have resulted? 2) How would the British have taken it? 3) We still need your help." The comment about the British was a reference to the Italian invasion of Ethiopia on October 3, 1935, just two months before Pius XI made his decision about a new Jesuit cardinal. The League of Nations had imposed sanctions on Italy in November; the Hoare-Laval Pact which yielded to many of the Italian territorial demands on Ethiopia had been leaked on December 13, and British and French public opinion was outraged. The pope seems to have feared that his promotion of a prominent Jesuit so closely linked to Mussolini would be seen by the British as an expression of political partisanship.

Venturi's anti-Jewish attitudes is his report to Vatican Secretary of State Cardinal Luigi Maglione on August 29, 1943, regarding his intervention with the new minister of the interior in Marshal Pietro Badoglio's government after Mussolini's fall from power. The intervention concerned possible modifications of the racial laws. Tacchi Venturi explained to Maglione that he had told the new minister that his proposals were intended to benefit only Jews who had converted to Catholicism. He stressed to Maglione that in his dealings with the Badoglio government he had not "alluded in any way to the total abrogation of laws which, according to the principles and tradition of the Catholic Church, have some dispositions that should be abrogated but contain others worthy of confirmation." See Actes et documents du Saint Siège rélatifs à la seconde guerre mondiale [hereafter ADss] (Vatican City: Libreria Editrice Vaticana, 1965-81), doc. 317, TacchiVenturi to Maglione, August 29, 1943, 9:458-59.

18 See a typed copy of Tacchi-Venturi's report, with minor editing marks, in ARSI, TV, Misc, b. 11, fol. 38, "La promozione del P. Pietro Boetto al cardinalato," 1. Martina, "La mancata nomina," 106-9, prints the ARsI document in full, with the exception of the last two paragraphs. 
On this point, however, Pius XI was not entirely forthright with Tacchi Venturi, for the pope had not been reluctant in December 1935 to offend the British with some of his other appointments of new cardinals. For example, he had deliberately overlooked the new archbishop of Westminister, Arthur Hinsley (1865-1943), who had been expected to be elevated. Hinsley had criticized Mussolini and the Fascist regime and spoken of the pope in what was considered a demeaning fashion. Yet while Hinsley was unacceptable, Pius XI had elevated his old friend and associate Monsignor Camillo Caccia (1877-1946), who had often been accused of sexual predation and pederasty. ${ }^{19}$ In addition, of the twenty new cardinals elevated at the 1935 consistory, fourteen were Italians and most of those had expressed their support of the Fascist regime. On the other hand, by overlooking Tacchi Venturi, the pope had, at least according to that Jesuit's account, surprised and irritated Mussolini. The pope was conducting a careful and subtle balancing act.

In his report in the mid-1940s, Tacchi Venturi stated that Pius XI informed him during the audience in 1936 of yet another reason for his failure to elevate him. According to established procedures, the pope was obliged, when elevating a priest in a religious order, to advise the head of the order beforehand. Accordingly, Pius XI advised Ledóchowski of his choice of Tacchi Venturi, and Ledóchowski balked. According to Tacchi Venturi, Ledóchowski replied that, if the pope was determined "to exempt a priest of the Society from the vow made by the Professed" to abstain from seeking ecclesiastical promotion, he should consider Boetto. Tacchi Venturi did not speculate as to why Ledóchowski opposed his own appointment, except to say that the superior general held Boetto in high esteem for the many services he had performed for the Society and wanted him to continue "to render them in a different form from a more elevated position." At the same time, Tacchi Venturi denigrated Boetto in his account, describing him as "an exemplary and amiable religious, without doubt, but lacking in everything [tutti i titoli] for which the Popes had imposed the sacred Purple on religious in the former and the modern Society."20 The phrase is awkward in the original, but the point is clear enough. Tacchi Venturi was, even after ten years, bitter indeed.

In 1996, a Jesuit historian offered another explanation for Ledóchowski's opposition to the pope's proposal of Tacchi Venturi for the cardinalate. The superior general of the Society, he wrote, may have been concerned that an already prominent priest in his order, should he receive the great honor of the cardinalate, would challenge his own authority and be difficult to control. ${ }^{21}$ But

19 Kertzer, Pope and Mussolini, 227-29.

20 Tacchi Venturi report, ARSI, 1; and Martina, "La mancata nomina," 107.

21 Martina, "La mancata nomina," 104. 
whatever the reasons, on December 16, 1935, the pope, with input from the superior general of the Society of Jesus, announced the elevation of the stable, steady, and totally dependable Boetto rather than the talented but far more fiery and political Tacchi Venturi to be his new Jesuit cardinal deacon. Boetto's primary duties would involve full-time service to the Roman Curia. Accordingly, already by 1936 he had been assigned to five different Roman congregations, including Chiesa Orientale, Sacramenti, Religiosi, Seminari ed Università degli Studi, and Propaganda Fide. ${ }^{22}$

Nor, apparently, did the pope ever regret his choice, for less than three years later he selected Cardinal Boetto to be the next archbishop of Genoa. ${ }^{23}$ The designation was highly unusual, for while it was rare for a priest who had not yet served as a bishop to be sent as archbishop to one of Italy's major dioceses, it was even more exceptional for a Jesuit to receive an ecclesiastical appointment of any kind. And again, the decision involved humiliation for Tacchi Venturi, who recorded it in his account in the mid-1940s. On March 13, 1938, the current archbishop of Genoa, Cardinal Carlo Dalmazio Minoretti (1861-1938), died. The timing was delicate, for Adolf Hitler (in office 1933-45) was scheduled to tour Rome, Naples, and Florence for about a week beginning on May 3, and Mussolini was to visit Genoa on May 14. Pius XI was determined to have a new archbishop of Genoa installed before those visits occurred. According to the 1929 Lateran Accords between the Holy See and Italy, the pope was obliged to inform the Italian head of government of any new ecclesiastical appointments and receive his agreement in advance. Therefore, at about 11 o'clock on the morning of March 16, just three days after Minoretti's death, Pius XI asked Tacchi Venturi to meet with Mussolini immediately. When the Jesuit did so, the Duce made no objections to Cardinal Boetto's appointment. Mussolini also agreed to waive the usual month-long waiting period between his notification and the Vatican's public announcement of a new ecclesiastical selection. But in the process, Mussolini was again in a position to focus on Tacchi Venturi's humiliation of 1935, which he, Mussolini, regarded as a personal affront from Pius XI.

For Tacchi Venturi, worse was yet to come. When he returned a little before one o'clock in the afternoon to tell the pope of Mussolini's agreement, Pius XI asked him to inform Ledóchowski that same afternoon. Tacchi Venturi arrived at the office of the superior general at three o'clock to find Cardinal Boetto also outside the door. Boetto had already been informed of the appointment; according to Brother Weidinger, he had been summoned by the pope about

22 Annuario Pontificio: 1936 (Vatican City: Libreria Editrice Vaticana, 1936), 56-57.

23 The point about the pope having no regrets was made in Martina, "La mancata nomina," 105 . 
eleven o'clock that same morning, and thus perhaps even before Tacchi Venturi had received Mussolini's agreement. Boetto had tried to protest that he had little experience of diocesan and parochial matters, but Pius XI had informed him that it was God's will. ${ }^{24}$ Tacchi Venturi entered the office first and spoke privately with Ledóchowski, whose unexpressed but obvious annoyance he noted in his account years later. After all, the pope had not asked Ledóchowski for his agreement but had simply informed him of his decision. This was despite the fact that the superior general, like others before him, had tried to discourage the appointment of Jesuits to ecclesiastical positions. Tacchi Venturi went on to record that he never told Ledóchowski that the pope had instructed him to inform Mussolini of his decision before meeting with the superior general. Nor did he ever tell his Jesuit superior that the pope had told him of the real reasons why he had not received the cardinalate three years earlier. ${ }^{25}$

The following day, March 17, 1938, Pius XI elevated Boetto to the position of cardinal priest and named him archbishop of Genoa. About a month later, the new cardinal met with King Victor Emanuele at the Quirinale Palace. Consecrated archbishop on April 24, he quietly left Rome on May 8 from a local railroad station bedecked with Italian and German flags and flowers in honor of Hitler's visit. In Genoa, on the other hand, he was met with a sumptuous ceremony of welcome. ${ }^{26}$

Cardinal Boetto was to enjoy little more than two years of peace in his archdiocese before Mussolini entered the war on the side of the Third Reich on June 10, 1940. He was clearly a particular kind of ecclesiastic; he was not an intellectual, a specialist in theology and philosophy, or even an exceptionally inspiring speaker. Nor did he have a reputation like that of his predecessor, Archbishop Minoretti, as a "social bishop," sometimes critical of the excesses of capitalism and even of Mussolini and a single-party state. ${ }^{27}$ Cardinal Boetto's strengths lay

24 Weidinger's account is quoted in Lanz, Cardinale Pietro Boetto, 276-77. It is possible that Weidinger was mistaken about the timing.

25 Tacchi Venturi report, ARSI, $3-4$.

26 For Weidinger's lengthy and colorful first-hand descriptions of the period between the nomination of Boetto as archbishop and his welcome in Genoa, see his "Memorie sul compianto Cardinale Pietro Boetto-Arcivescovo di Genova (1938)," 1-22.

27 For more on Minoretti, see Danilo Veneruso, "Il dibattito politico-sociale nella chiesa genovese durante l'episcopato del card. Carlo Dalmazio Minoretti (1925-1938)," in Paolo Pecorari, ed., Chiesa, Azione Cattolica e fascismo nell'Italia settentrionale durante il pontifcato di Pio XI (1922-1939) (Milan: Vita e Pensiero, 1979), 3-62. There is no evidence that 
in administration and organization, and that, combined with his kindness and personal touch, enabled him to fulfill his responsibilities well. He spent the brief period before the war familiarizing himself with the clergy, religious, and parishioners in the archdiocese. He also played an active role in the public life of the city of Genoa, participating in or presiding over ceremonies and events such as the hosting of the XxIV Congresso degli universitari cattolici in 1938 . He travelled often to Rome for church business, most notably after the death of Pope Pius XI on February 10, 1939. At that time, he was among the sixty-two cardinals to participate in the conclave that elected Cardinal Eugenio Pacelli on the third ballot, on March 2, as the new pope. Pacelli took the name of Pius XII. ${ }^{28}$

The outbreak of war initiated horrifying new challenges. The British bombed Genoa on June 11 and 12, 1940, just a day or two after the Italian declaration of war. Subsequent raids were sporadic but intensified with time. A naval bombardment on February 9, 1941, damaged, among other buildings, the Cathedral of San Lorenzo and Genoa's major hospital, causing seventy-two deaths and 226 injuries. Still more terrible were the air raids on October 22, 1942, and others in the days that followed. Air raid shelters proved inadequate, and thousands were left without homes, foodstuffs or medicines. Train stations and tracks were destroyed, the harbor clogged, roads unpassable, schools and churches damaged, and hospitals overwhelmed with the injured and dying. Further raids in the spring of 1943 brought on labor strikes and protests for peace. But the worst was still to come. In five years of war, Genoa suffered eighty-six air raids, but fifty-one of them were in 1944. Civilians were targeted rather than military or industrial installations. The center of the city was virtually flattened. Cardinal Boetto's offices in the Archbishop's Palace were directly hit on May 19.

Throughout the war, Cardinal Boetto was tireless in his efforts to aid the afflicted. His most immediate responsibility was for the welfare of the secular clergy and the religious - the priests, brothers, and nuns whose institutions had been destroyed and who had little sustenance. But he also worked extensively among the poor, establishing soup kitchens and urging priests under his jurisdiction to take in the homeless. He visited bombed areas, publicly expressing his outrage and condemning deliberate aerial attacks on civilians from whatever source. More privately, on November 8, 1942, he sent an anguished

Boetto was "a Jesuit of anti-Fascist sentiments" or that Pius XI elevated him for that reason, as alleged by Vincent A. Lapomardo, S.J., in "The Cardinal of the Persecuted Jews," original pub. 1988, updated 2000 (accessed April 13, 2020). 
message to Pius XII, describing the awful suffering in Genoa caused by the bombing raids and begging the pope to intervene in some appropriate way on the city's behalf. In response, he received a letter from the pope on November 16 , expressing the latter's sorrow at the suffering and promising to do everything possible. ${ }^{29}$

Without taking a political position, Boetto nevertheless intervened with the authorities on behalf of imprisoned dissenters, always urging moderation and mercy. He wrote to Italian soldiers in North Africa or on the Russian front and tried to comfort their families. He presided over countless funerals and special Masses. His problems multiplied after Mussolini fell from power on July 25, 1943, and then again after the Duce's replacement, Marshal Pietro Badoglio (1871-1956), signed an armistice with the Allies, announced on September 8. As American and British troops landed in the south and began their slow crawl up the Italian peninsula, the Germans occupied most of the country and reinstated Mussolini as head of the new Italian Social Republic (the Republic of Salò). Internal opposition to the occupiers and their Fascist allies grew rapidly, and young men fled the cities to join the partisans. Now lethal political problems were added to the cardinal's ongoing concern for the spiritual and economic welfare of his people.

During the remaining twenty months of occupation and war, Boetto tried to maintain a position of neutrality, judged best to enable him to continue his ministry and negotiate with the Germans and their Fascist supporters on behalf of clergy and laypersons in trouble. To avoid the obligation to submit to German censorship, he suspended publication of Il Nuovo cittadino, Genoa's Catholic daily newspaper, immediately after the onset of the occupation in early September and did not resume it until liberation. Henceforth, notices from the diocesan office were printed briefly in La Settimana religiosa. In those notices and in his continuous speeches and messages, the cardinal-archbishop urged the civilian population to respect the secular authorities, refrain from violence, help maintain public order, and adhere to Catholic teachings regarding moral behavior and compassion for human suffering. He also added explicit admonitions that civilians should refrain from informing on their neighbors.

Boetto never publicly condemned Italian participation in the war, the Fascists, or the German forces of occupation. Throughout the conflict, he remained on cordial terms with some German military and civilian officials in the city, especially the German consul general. Through those lines of communication, he was able to issue pleas for restraint and intervene on behalf of

29 The text of Boetto's letter is in Lanz, Cardinale Pietro Boetto, 419-20; the pope's response is printed in part in Lanz, Cardinale Pietro Boetto, 420. 
arrested priests, anti-Fascists, partisans, and Jews, with varying degrees of success. He permitted his priests to minister not only to Italian soldiers in the service of the Republic of Salò, but to Fascist fanatics in the most repressive and cruel anti-partisan militias. Similarly, he allowed priests to minister to the partisans, including Communists. But while spiritual assistance was acceptable for priests, political advocacy was not. Brother Weidinger recalled, for example, that during the German occupation Boetto refused every appeal to meet personally with a military chaplain who was coming to Genoa to make a pro-Nazi and pro-Fascist speech. ${ }^{30}$

Better recorded than Boetto's general wartime measures are his activities on behalf of Jews in and around Genoa. The new archbishop had been at his post barely three and a half months when the Fascist regime's first anti-Jewish decrees were issued in early September 1938. Though not imposed on Mussolini by Hitler, the laws resembled those in effect in the Third Reich at that timeJews were prohibited from owning property or businesses over a certain value; they could no longer hold positions in public service, the military, or the professions; they could not teach or send their children to public schools; and inter-marriage was prohibited. Jews in Italy were defined as individuals with two Jewish parents; the children of mixed marriages were considered Jewish unless they had been baptized before October 1, 1938, or at birth. In addition, foreign Jews were ordered to leave the country within six months. Included in this expulsion order were foreign-born Jews who had been naturalized after January 1, 1919.

Under these circumstances, Boetto and his assistants before the German occupation could be most helpful to Jews in two ways. First, they could falsify or backdate baptismal certificates, a step which, at least before the most terrifying years of actual deportations, was almost always confined to those who had some connection with Catholicism. But the conversion of individuals with

$30 \quad$ Weidinger's story is from his "Memorie sul compianto Cardinale Pietro Boetto," 56. For more on Boetto's general wartime work and teaching both before and during the occupation, see Lanz, Cardinale Pietro Boetto, 379-564; Giovanni Battista Varnier, "Un vescovo per la guerra: L'azione pastorale del Cardinale Boetto, arcivescovo di Genova (1936-1946)," in Cattolici e resistenza nell'Italia settentrionale, ed. Bartolo Gariglio (Bologna: Società Editrice Mulino, 1997), 33-57, esp. 42-49; Varnier, "La Chiesa genovese dalla 'grande guerra' alla Resistenza: Cenni storico-istituzionali," in Italia contemporanea, 45-62, esp. 59-61; and Danilo Veneruso, "I cattolici genovesi e la seconda guerra mondiale (1939-1943)," Storia e memoria: Istituto storico della Resistenza in Liguria, anno 2, n. 2 (1993): 41-52. 
two Jewish parents provided no protection from persecution, making baptismal certificates of little value to them if the authorities did background checks. Priests in Genoa and elsewhere may have provided backdated and, occasionally, falsified certificates to both genuine converts and spouses and children in mixed marriages, but the frequency of such activity was limited, and the evidence is thin.

More frequently, priests could help some of the thousands of desperate Jews, including Italians, foreign-born residents, and recently arrived refugees without legal documents, who wanted to emigrate but could not find the means. Many hopeful emigrants, particularly foreigners, found themselves in Genoa because the city was a major port. Emigration was extraordinarily difficult, however, because those involved not only needed secure destinations abroad, but money for passage, temporary housing and provisions before leaving, and identification and travel documents. A Jewish organization called the Delegazione Assistenza Emigranti Ebrei (Delasem) existed to help prospective emigrants who were Jewish by religion or culture, but its resources were limited. It was clearly understood that the church would help Jews who had converted or were part of mixed families.

Boetto was willing to help. Surviving documents provide evidence of his activity in this regard, before the German occupation almost always on behalf of Jews with some Catholic connection. ${ }^{31}$ However, the documents do not usually indicate the origin, extent, or dates of specific cases of assistance. It is not clear how closely Boetto worked with Delasem before the occupation; whether those he helped came to him directly or were referred to him by the Jewish agency; and whether his assistance efforts intensified or diminished after Mussolini took Italy into the war and began rounding up foreign Jews for internment. ${ }^{32}$ Nor is the source of funding for these early assistance operations fully

31 Archivio Diocesano di Genova (ADG), Carte Boetto, fol. 10, Lettere per ebrei. See also examples cited in Carlo Brizzolari, Gli ebrei nella storia di Genova (Savona: Sbatelli, 1971), 289-91; and Weidinger, "Memorie sul compianto Cardinale Pietro Boetto," 35-38. Weidinger makes it clear that the examples he describes in detail are of Jews who were Catholics or were connected to Catholics.

32 Boetto had contact with Lelio Vittorio Valobra, the national director of Delasem based in Genoa, at least by the summer of 1941. Valobra asked Boetto for help with efforts by Delasem to aid Jews interned in coastal areas in Italian-occupied Croatia, and Boetto suggested that he contact Monsignor Giovanni Battista Montini, secretary of the Section for Ordinary Ecclesiastical Affairs at the Vatican Secretariat of State (future Pope Paul vi [r.196378]). See a copy of a letter from Valobra to Jewish Community leader Lionello Alatri (1978-1943) in Rome, August 11, 1941, in Settimio Sorani (a Delasem activist in Rome at the time), L'assistenza ai profughi ebrei in Italia (1933-1947) (Rome: Carucci, 1983), 249-50. It is not clear that Boetto was otherwise involved with this effort. Renzo De Felice's (1929-96) 
clear. It is known that Boetto received some 45,00o lire from the Vatican in the spring of 1940, to be used to assist Jewish refugees. That money was part of a gift of $\$ 125,000$ to the Vatican from the United Jewish Appeal in the autumn of 1939 in honor of Pius XI, to be spent on behalf of "refugees of every race, faith, and color." ${ }^{33}$

During the period from June 10, 1940, to September 8, 1943, when Italy was at war on the side of the Third Reich but not yet under German occupation, Boetto became more aware of the rapidly escalating extermination of Jews in the East. It is not clear how much he knew of massacres of Jews by German Einsatzgruppen advancing through Soviet-controlled territories in the summer and autumn of 1941. He received other news, however, on or about April 11, 1942, when an Italian officer recently returned from Budapest visited him in his office. The officer told him that Jewish refugees in Hungary were being arrested and confined to camps along the border with no facilities or services, where most of them were dying. In addition, according to the same officer, thousands of young Jewish women in Slovakia were being arrested and forced into prostitution. The officer begged Boetto to inform Vatican officials, which he did on April 16. ${ }^{34}$ Vatican Secretary of State Cardinal Luigi Maglione (1877-1944) replied on the $21^{\text {st }}$, explaining that he had already been informed of these and

often repeated statement about a different exchange two years later, "On the eve of the fall of Fascism, negotiations were underway between Valobra and the Holy See-through Cardinal Boetto- to transfer six hundred children to Turkey," seems exaggerated and doubtful. De Felice's evidence was a letter from Boetto to Valobra on July 6, 1943, explaining that the Vatican secretary of state had asked him, Boetto, to inform Valobra that the Holy See could not cooperate with Valobra's rescue proposal of the preceding May. But that same letter from Boetto indicated that he had not been involved with the original proposal or any subsequent negotiations with the Vatican. Boetto clearly stated that the proposal had been made by Valobra, by means of Dr. Gustavo Volterra, a friend of Valobra and a leader of the Roman Jewish Community active with Delasem at the time. See Renzo De Felice, Storia degli ebrei italiani sotto il fascismo, $4^{\text {th }}$ ed. (Turin: Einaudi, 1988), 432; and a copy of Boetto's letter to Valobra in Varnier, "Un vescovo per la guerra," 57. The original letter is in Carte Boetto, fol. 10, Lettere pro Ebrei.

33 ADSs, doc. 52, notes of the Secretariat of State, August 26, 1939, 6:122-23; doc. 135, notes of Montini and Tardini, January 22 and 23, 1940, 223; and doc. 215, notes of the Secretariat of State, May 25, 1940, 322. For details on how the rest of the $\$ 125,000$ was distributed, see Susan Zuccotti, Under His Very Windows: The Vatican and the Holocaust in Italy (New Haven: Yale University Press, 200o), 77. Brizzolari, Gli Ebrei nella storia di Genova, 289, refers to twenty thousand lire sent to Boetto, quotes from a letter from Montini to Boetto, does not give a precise date, and cites ADG, Carte per la storia ecclesiastica ligure (1938-45), April 15, 1940. It is not clear whether there were two separate distributions to Boetto.

34 Boetto to Maglione, April 16, 1942, printed in full in Varnier, "Un vescovo per la guerra," 53-54. It might be noted that Boetto did not mention, and probably had not been told of, the deportations of tens of thousands of Slovakian Jews to Auschwitz occurring at about 
other atrocities and had intervened several times with the appropriate authorities. ${ }^{35}$ Boetto's efforts had made no direct difference in these cases, then, but they indicate his awareness of atrocities at a relatively early stage.

Deportations and massacres of Jews in Italy began with the onset of the German occupation on September 8, 1943. On September 16, German SS troops arrested sixteen Jewish men, women, and children in Meina, on the shores of beautiful Lago Maggiore, and brutally murdered them all on the $22^{\text {nd }}$. On the $18^{\text {th }}$ in the province of Cuneo, they arrested 349 Jewish refugees who had fled across the Maritime Alps from southeastern France, formerly occupied by the Italians and now in German hands, into Italy, and imprisoned them in Borgo San Dalmazzo. Of these, 330 would be deported to Auschwitz in November and only a handful would survive. Similar atrocities occurred throughout Italy during the first two months of occupation, of which the largest and best known was the roundup in Rome on October 16 of some 1,259 Italian Jews, followed by the deportation of 1,023 of them on the $18^{\text {th }}$. Clearly, Delasem's Jewish activists would now have to go underground. In Genoa, Delasem's national director Lelio Vittorio Valobra $(1900-76)$ turned to the non-Jewish acquaintance most able to help him. That man was Boetto.

Don Francesco Repetto (1914-84), a twenty-eight-year-old priest and Cardinal Boetto's secretary at the time, later recorded how Valobra came to his office a few weeks after September 8 to ask if he, Valobra, could turn over Delasem's funds and client lists to Boetto. Could the cardinal take over the work of finding shelter and delivering life-supporting subsidies to Jews now obliged to go into hiding in Genoa? The cardinal agreed immediately and put don Repetto in charge of what became a wide-spread rescue operation. ${ }^{36}$ At about the same time, he and don Repetto found a hiding place in an apartment near the synagogue for Riccardo Pacifici (1904-c.1943), the chief rabbi of Genoa. When Rabbi Pacifici was lured to a meeting and caught by German SS agents after the

the same time or the expulsions from Hungary and subsequent massacres of thousands of foreign Jews in August 1941 and January 1942.

35 Maglione to Boetto, April 21, 1942, in ADss, doc. 357, 8:513-14. The letter is also preserved in ADG, Carte per la storia ecclesiastica ligure (1938-45), April 21, 1942.

36 Francesco Repetto, "La consegna della Medaglia dei Giusti fra le Nazioni," Liguria, anno 49, n. 3 (May-June 1982): 27-30, at 29. 
first large roundup of Jews in Genoa on November 3, 1943, Cardinal Boetto wrote a long appeal for his release to the Italian chief of the province. The appeal was ignored, and Rabbi Pacifici died at Auschwitz. ${ }^{37}$

Despite the tragedies of early November, don Repetto's rescue operations grew ever larger and more effective. He met regularly with Delasem leaders and activists in his office in the Archbishop's Palace. ${ }^{38} \mathrm{He}$ not only recruited priests and laypersons to find safe houses, distribute subsidies and provide moral support to those in hiding in Genoa, but on Cardinal Boetto's authority he contacted bishops and archbishops elsewhere to ask them to do the same. ${ }^{39}$ Escape routes to Switzerland were organized, with young priests and laypersons acting as guides. Hundreds of Jews were saved. When don Repetto barely escaped arrest and was forced to go into hiding in July 1944, don Carlo Salvi took his place. When two monsignors were arrested for these activities, Boetto intervened with the occupation authorities to obtain their release. Meanwhile, the cardinal and his assistants sheltered Jews in religious institutions throughout Genoa, including, in at least one instance, the Archbishop's Palace. Don Repetto also remembered a case in which Boetto asked the mother superior in a convent that was already sheltering a Jewish mother and child to lift the rules regarding men and accept the husband as well. ${ }^{40}$ The money for these operations came from the Delasem funds Valobra had originally entrusted to the cardinal. When those funds were exhausted, more money was collected by Jewish contributors and organizations in Switzerland and funneled into Genoa by Valobra, who had fled from Italy with his family at the end of November

37 On hiding Rabbi Pacifici, see “Testimonianza di Mons. Francesco Repetto," Commemorazione di Riccardo Pacifici, Genova, 13 giugno 1984, ed. and printed privately by Emanuele Pacifici, Rome, 1985, 21-24; and Repetto, "La consegna," 28. The full texts of Boetto's appeal and the answer he received are printed in Brizzolari, Gli ebrei nella storia di Genova, 308-9.

38 For one heroic Delasem activist's testimony about such meetings, see "Conversazione con il Sig. Massimo Teglio, Genova, 19 Gennaio 1965," Teglio in conversation with Rev. Aldo Luzzatto, Delia Sdraffa, and Pupa Dello Strologo, in Centro di documentazione ebraica contemporanea (CDEC), Milan, b. 13-B-Comunità ebraiche in Italia dal 1922 al 1945, folder Genova.

39 Regarding Repetto and the bishop of Chiavari, see "Conversazione con il Sig. Massimo Teglio," 1; regarding similar contacts in Milan and Turin, see Zuccotti, Under His Very Windows, 233-50. 
$1943{ }^{41}$ Boetto in turn relayed Delasem funds to rescue teams in Rome and throughout the country. ${ }^{42}$

Don Francesco Repetto and don Carlo Salvi were honored by Yad Vashem as Righteous among the Nations in 1976. Cardinal Pietro Boetto was similarly honored, posthumously, in 2016.

Despite all that had come before, the last two or three months of the German occupation were the most harrowing of the war for the people of Genoa, including Cardinal Boetto. In the spring of 1945, German military officers had strict orders from Berlin to destroy the port and the city's infrastructure if and when they were obliged to withdraw. General Günther Meinhold (1889-1979), commander of German forces in the sector of Genoa, understood that such destruction would provoke a general insurrection and lead to hundreds if not thousands of unnecessary deaths on both sides. His chief concern was to get his troops out of the Ligurian pocket and onto the plains of the Po, from where they could head for the Brenner Pass and help defend their homeland. He hoped to negotiate a deal with local partisans, represented by individuals from six anti-Fascist parties in an organization called the Comitato di Liberazione Nazionale per la Liguria (CLN-Liguria), to allow his soldiers to pass through the mountains undisturbed if they did not destroy the city. The CLN refused any such deal.

Boetto was one of several who tried to bring the two sides to some kind of an understanding. He intervened with both Italian Fascist and German military

41 Valobra later recorded that he left three million lire with Delasem in Genoa in November 1943 and sent an additional twenty-seven million lire there from Switzerland between January and June 1944, plus smaller amounts in the autumn of 1944 and the winter of 1944-45. See Valobra letter to Renzo Levi, October 31, 1944, in CDEC, Fondo Valobra, b. 14, fasc. H, and printed in part in Sandro Antonini, Delasem (Genoa: De Ferrari, 200o), 28788; and Michele Sarfatti, "Raffaele Jona ed il soccorso agli ebrei del Piemonte durante la Repubblica Sociale Italiana," Questioni di storia della Valle d'Aosta contemporanea 3 (1990): 76-95, at 79 .

42 For distribution to Rome, see Lelio Vittorio Valobra, Renzo Levi, and Settimio Sorani [all wartime Delasem activists], "Risposta a Civiltà Cattolica," Israel, anno 46, n. 32 (June 8, 1961): 1; and Maria Benedetto, "Alcune precisazioni di Padre Benedetto," Israel 36 (July 6, 1961): 5. The first three writers explained that Padre Benedetto, an activist with them in Delasem's Jewish rescue operation in occupied Rome, had received one million lire from Delasem in Genoa. Benedetto confirmed, explaining that he had travelled to Genoa in April 1944 to collect the one million lire from the funds that Delasem had entrusted to Cardinal Boetto. He added that he and Delasem in Rome received no funding from the Vatican. For details, see Zuccotti, Père Marie Benoit and Jewish Rescue, 179-81. 
and diplomatic authorities on several occasions, pleading for moderation and fair treatment of political prisoners and pointing out the terrible consequences of any massive destruction of local facilities. He also encouraged his associates, including, most importantly, Siri, his auxiliary bishop, to continue negotiations with all concerned parties in an effort to restrain them. In the end, partisans blocked a German retreat but Meinhold nevertheless agreed to an unconditional surrender without the destruction of the city. The final difficult negotiations between Meinhold and representatives of the CLN took place throughout the night of April 25-26, 1945, at the Villa Migoni, Boetto's temporary residence after the Archbishop's Palace was damaged in an air raid. The cardinal acted as host at the negotiations, but not a participant. According to Brother Weidinger, Meinhold asked the cardinal to participate but he declined, saying, "We are not politicians and the Church cannot intervene in the struggles of the profane powers, but my house will be open for as long as it is desired."43 The act of unconditional surrender was signed and went into effect at 9 am on the $26^{\text {th }}$. Genova was liberated with little violence.

The months following liberation and the end of the war were difficult, as Italians dealt with death and destruction, displacement, scarcities, and impoverishment. Through it all, Cardinal Boetto ministered to his flock as he had always done. He was widely admired for the courage, faith, and integrity he had demonstrated during the conflict and for his compassion and assistance to the people of Genoa. Often called "the cardinal of the Liberation," he was awarded honorary citizenship by the grateful city in a ceremony at the Consiglio Comunale on December 8, 1945. He attended countless other formal ceremonies that year, often in celebration of liberation and the war's end, and equally often in recognition of his role by groups of citizens anxious to thank him. And he met with hundreds of individuals and groups-men and women of the church, political and trade union leaders, factory workers and social welfare activists,

43 Meinhold, quoted in Carlo Brizzolari, Un archivio della resistenza in Liguria (Genoa: Di Stefano Editore, 1974), 342. See also Boetto, "Atti di S. Em. Il Card. Arcivescovo, 'Ne permeant...," Rivista diocesana (1945): 27-31; Giuseppe Siri, "Memorie sulle vicende genovesi 1944-1945," Rivista diocesana genovese 3 (1975): 174-90; and Lanz, Cardinale Pietro Boetto, 585-97. Among many general accounts, see Carlo Brizzolari, Genova Piano Z: Storia del 25 aprile (Genoa: Editrice Realizzazioni Grafiche Artigiana, 1971); Mauro Montarese, Genova brucia 1940-45 (Genoa: Editrice Realizzazioni Grafiche Artigiana, 1971); Paolo Emilio Taviani, Breve storia dell'insurrezione di Genova (Genova: n.p., 1956); Elisabetta Tonizzi and Giovanni B. Varnier, "Alfredo Romanzi (Stefano): Una testimonianza," Storia e memoria: Istituto Storico della Resistenza in Liguria, anno 3, n. 1 (1994): 97-118; and Resistenza e ricostruzione in Liguria: Verbali del CLN, ligure 1944/1945, ed. Paride Rugafiori (Milan: Feltrinelli, 1981). 
educators, survivors of imprisonment and deportation. All this in addition to his regular pastoral and administrative duties.

But he was not well. Brother Weidinger noted that priests and prelates who saw him at a gathering in Rome at the end of May 1945 found him greatly aged, pale, and bent. ${ }^{44} \mathrm{He}$ persisted with his activities as long as he could, but he finally yielded to illness in the middle of January 1946 and took to his bed. He died two weeks later, on January 31, at the age of seventy-four. His body rests in the crypt beside the altar in the Cathedral of San Lorenzo in Genoa. The plaque in Latin says simply "PETRUS Card. BOETTO, S.J. Archiep. Genuen. Civitatis Defensor. 1871-1946. (Cardinal Pietro Boetto, S.J. Archbishop of Genoa. Defender of the City.)

\section{Conclusion}

Cardinal Boetto was a remarkable man, both in his steady, hard-working dedication to his traditional responsibilities as a Jesuit priest and in his ability, during the war, to tend to all men and women in need, whether Fascists or Communists; Catholics, Protestants, Jews, or atheists. Nothing in his formation or work experience as a Jesuit had prepared him to minister to those beyond his faith; he had, until 1940, relatively little contact with the world outside his church. He was not alone among his colleagues and peers at the time. Catholic spokesmen of his generation often still felt themselves besieged by secular, modernist, anti-clerical forces, and believed it was their job to defend their institution and their flock against a hostile world. At best, they believed that non-Catholics would organize and find their own means of protection and support.

It should be remembered also that Boetto never took a position against Mussolini's authoritarian Fascist state. He did not condemn Mussolini's antiSemitic decrees before the war, or express sympathy for anti-Fascist dissidents lingering in prisons and camps throughout the country in the 1930s and early 1940s. He preached obedience, respect for authority, and non-confrontation even during the German occupation. He seems to have fully shared the position of many Catholic leaders in Italy and elsewhere that the church should remain neutral and non-partisan in political issues, to better minister to the faithful and maintain dialogue, restrain violence, and help negotiate an eventual peace. None of this prepared Boetto for the challenges of the German 
occupation, when helpless and terrified men, women, and children of all nationalities, races, and faiths appealed to him for assistance.

Cardinal Boetto rose to the occasion without hesitation, and found young priests and laypersons willing to risk their lives for others, for all others, for total strangers, foreigners, Communists, atheists, Jews. In part he was able to do this because of his own personal goodness and humanity. But in part it was because times had changed. Italian Catholic leaders no longer felt besieged by an alien and hostile secular society. The First World War had brought many of them into the body politic. The Lateran Accords between the Holy See and the Italian state in 1929 had solved legal controversies and eased the way toward reconciliation. And then Nazi barbarism made many Catholic priests and prelates understand the need to join all segments of the society in resistance. Cardinal Pietro Boetto and his assistants saved lives. They were also part of a changing church that defined its responsibility to humanity in general, rather than limiting it to those who shared the faith. They helped make the church what it is today. 